\title{
About the translations of the French Commercial Code of 1807 into Polish ${ }^{1}$
}

The French Commercial Code (Code de commerce), promulgated in the country in September of 1807, was introduced in the Polish territories a year and a half later. ${ }^{2}$ It was previously claimed in the literature on the subject that the code was formally in force almost without any alterations until the introduction of the Polish

\footnotetext{
${ }^{1}$ A. Klimaszewska, O tlumaczeniach francuskiego Kodeksu handlowego z 1807 roku na język polski, "Czasopismo Prawno-Historyczne" [Journal of Law and History] [CPH] 2012, vol. LXIV, issue 1, pp. 141-147.

${ }^{2}$ In the Duchy of Warsaw pursuant to the Act of 24 March 1809; "Prawo stanowiące przyjęcie Kodexu Handlowego Francuzkiego dla Księstwa Warszawskiego" [Law authorizing the adoption of the French Commercial Code in the Duchy of Warsaw]; "Dziennik Praw Księstwa Warszawskiego" [Journal of Laws of the Duchy of Warsaw] (hereafter: DPKW), vol. 1, p. 239. More on the subject of Code de commerce: A. Klimaszewska, Code de commerce - francuski Kodeks handlowy z 1807 r. [Code de commerce: the French Commercial Code of 1807], Gdańsk 2011; eadem, Francuski Kodeks handlowy w Królestwie Polskim [The French Commercial Code in Congress Poland] [in:] L. Mażewski (ed.), System polityczny, prawo, konstytucja i ustrój Królestwa Polskiego 1815-1830 [Political system, law, constitution and system of government of the Kingdom of Poland between 1815 and 1830], Radzymin 2013, p. 187 et seq; eadem, La responsabilité civile des associés des sociétés commerciales dans le droit polonais - les influences de la culture juridique française et les influences des autres cultures [in:] Z. Hajn, D. Skupień (eds.), La responsabilité civile en France et en Pologne, Łódź 2016, pp. 131-146; eadem, Influence of French Legalese on the Development of Polish Legal Language Within the Area of Commercial Law [in:] E. Veress (ed.), Multilingualism and Law, Cluj-Napoca - Kolozsvàr 2016, pp. 173-184; eadem, The Reception of the French Commercial Code in Nineteenth-Century Polish Territories - A Hollow Legal Shell [in:] M. Gałędek, A. Klimaszewska (eds.), Modernisation, National Identity and Legal Instrumentalism. Studies in Comparative Legal History, vol. I: Private Law, Leiden - Boston 2020, pp. 143-163; eadem, Commercial judiciary on the Polish territories in the 19th century - a repackaged French product or a mock-up?, "Revista da Faculdade de Direito da Universidade Federal de Minas Gerais" 2019, special issue, eds. C. Vano, H. Pihlajamäki, R. Sontag, pp. 97-133.
} 
Commercial Code in 1934 in the Second Polish Republic. ${ }^{3}$ However, it should be taken into consideration that the small frequency and intensity of direct amendments of the provisions of the act did not mean a lack of legislative activity in the branch of commercial law. The activity more often than not contradicted the basic premise of the French code even while it was in force. A model example of this was the adoption of the resolution of the Viceroy of the Kingdom of Poland of the $11^{\text {th }}$ January 1817 (the so-called "Urządzenie kupiectwa" [Merchant Law]) without making any reference to the code. ${ }^{4}$ According to its provisions, a trade organization was sanctioned which was corporate in nature but it was not independent and it was also strictly controlled by the government, which stood in clear violation of the freedom to conduct business activities which was in turn the guiding principle of Code de commerce.

However, this act undoubtedly had an influence on the Polish legal culture for a period of time lasting almost 120 years when it was in force. The issue of its translation was incredibly problematic from the very beginning. The original French version was adopted as the official one. ${ }^{5}$ However, for practical reasons, several attempts to translate Code de commerce into Polish were undertaken over the course of the following decades. None of them can be classified as entirely satisfactory.

August Heylman, a judge of the Court of Appeal in Warsaw and the author of numerous works on various subjects, commercial law being one of them, correctly emphasized that "tłómaczenie kodexów wymaga jednocześnie głębokiéj umiejętności teoretycznéj i przenikliwéj wprawy praktycznéj, a zawsze trudném jest zadaniem, jeżeli język na który prawo z innego języka się tłómaczy, w tak zwane wyrazy techniczne nie obfituje: jak się to w języku polskim, w szczególności co do prawa handlowego uwydatnia" [the translation of codices requires both a deep theoretical skill and discerning practical expertise, and it is always a difficult task if the language into which a law is translated does not possess an abundance

${ }^{3}$ J. Bardach, B. Leśnodorski, M. Pietrzak, Historia ustroju i prawa polskiego [History of the system of government and law in Poland], Warsaw 1993, p. 426.

${ }^{4}$ DPKW, vol. 4, pp. 159-177.

5 “JW. Jarociński współkomisarz izby wymienionej z woli JW. marszałka sejmowego zabrał głos, w którym słownie przełożył, że komisya z JW. ministrem sprawiedliwości, a następnie z radą stanu, zgodziła się na to, jako jedynie kodeks handlowy francuski w języku francuskim za prawo ma być uważany, zaś tłumaczenie na język ojczysty jeszcze urzędowości nie nabyło [...]" [The Honourable Jarociński, a co-commissioner of the aforementioned house by the will of the Honourable Marshal of the Sejm, took the floor and then he verbally expounded that the commission, together with the Honourable Minister of Justice, and, subsequently, the Council of State, agreed that only the French Commercial Code, in French, is to be considered law, while the translation to the mother tongue has not acquired official status yet (...)]; M. Handelsman (ed.), Dyariusze Sejmów Księstwa Warszawskiego, zeszyt 1, Dziennik posiedzeń izby poselskiej sejmu r. 1809 [Diaries of the Sejms of the Duchy of Warsaw, issue 1, Journal of the sessions of the Chamber of Deputies in 1809], Warsaw 1913, p. 30. 
of technical vocabulary: it is visible in Polish, especially in case of commercial law]. ${ }^{6}$ An additional difficulty connected with finding proper technical legal terms in Polish stemmed from the fact that this vocabulary had been taking shape over centuries in France and it was practically not a part of the colloquial language in the $19^{\text {th }}$ century anymore. ${ }^{?}$

In Poland, Code de commerce was translated a total of thirteen times if one takes into account the changes in each version of the translation by a particular author. The first person to undertake this task was Walenty Skorochód-Majewski. He was a Warsaw archivist and notary by trade, while his interests lay in orientalism and sanskritology. Walenty Skorochód-Majewski was commissioned for the task by the Minister of Justice in 1808 even though he himself emphasized in the preface to his translation that his knowledge of trade relations was relatively low. ${ }^{8}$ That is why the understanding of the contents of certain provisions in the Polish version was and still is problematic to a large extent. Moreover, a number of serious discrepancies arose between this translation and the original text. The author himself was flooded with an enormous number of questions and requests for an interpretation for this very reason. ${ }^{9}$ It should also be mentioned that SkorochódMajewski adopted a different numbering of the $\operatorname{articles}^{10}$ in comparison to the one commonly used in the French editions of the Code or in the commentaries on it as well as in the translations into other languages. All of these reasons created further interpretative chaos.

${ }^{6}$ A. Heylman, Porównanie pobieżne sześciu tłómaczeń Polskich kodexu handlowego Francuzkiego odnośnie do początkowych jego rozdziałów [A cursory comparison of six Polish translations of the French Commercial Code pertaining to its initial chapters] [in:] idem, Zbiór rozpraw jurysprudencyjnych [A collection of jurisprudence disquisitions], vol. 2, Warsaw 1871, p. 82.

7 W. Sobociński, Historia ustroju i prawa Księstwa Warszawskiego [History of the system of government and law in the Duchy of Warsaw], Torun 1964, p. 201 et seq.; idem, O prawie francuskim $w$ Niemczech na poczatku XIX $w$. [French law in Germany in the beginning of the $19^{\text {th }}$ century], CPH 1981, vol. 33, issue 1, p. 201.

${ }^{8}$ Kodex handlowy z zlecenia JWgo Ministra Sprawiedliwości przettumaczony przez Walentego Skorochod Majewskiego wezwanego iako Notaryusza Publicznego [Commercial Code as ordered by the Honourable Minister of Justice and translated by Walenty Skorochód Majewski called on as Notary Public], Warsaw 1808, introduction.

9 S. Grodziski, Wpływy Code civil oraz innych kodyfikacji napoleońskich na ziemiach polskich [The influence of the Civil Code and of other Napoleonic codifications on Polish territories], "Czasopismo Prawno-Historyczne" [Journal of Legal and Historical Sciences] 2005, vol. 57, issue 2, p. 64.

${ }^{10}$ The Code itself as well as the majority of commentaries and translations of it employ continuous numbering of articles from 1 to 648. However, the Polish translator employed a numbering system which involved starting each book from article 1. In this context, the publication by J.F. Fournel, Code de commerce, accompagné de notes et observations, Paris 1807, was an exception. The author of the comment added his own numbering in brackets to the original numbering of the articles and he started each book from article 1 . 
The level of encountered complications as well as the vast gap in quality between the level of French and Polish legal language in the field of commercial law in the beginning of the $19^{\text {th }}$ century is also portrayed to a certain extent by the method of translation adopted at the outset. This method boiled down to attempts at creating Polish equivalents of the French words and at the same time leaving the original vocabulary items in the translation:

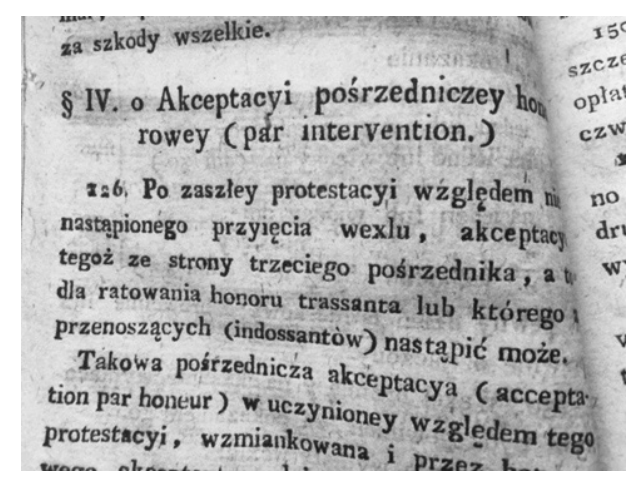

Translation of article 126 (Book 1, Title 8)

However, as judge Jan Chryzostom Sławianowski noted, Skorochód-Majewski "sam własnym prawie siłom zostawiony, nie mógł w chwilach swej pracy czerpać nauki i wyjaśnienia w autorach, którzy później naukę tę tak wysoko posunęli: jeszcze nie było Delwinkurów ${ }^{11}$, Pardessiuów ${ }^{12}$, Wincenów ${ }^{13}$, Nougierów ${ }^{14}$, Ro-

${ }^{11}$ C.-É. Delvincourt, Institutes de droit commercial français, avec des notes explicatives du texte, dans lesquelles on examine les principales questions qui peuvent s'élever sur les matières commerciales, vol. 2, Paris 1810.

12 J.-M. Pardessus, Cours de droit commercial, vol. 4, Paris 1813-1817.

13 É. Vincens, Exposition raisonnée de la législation commerciale, et examen critique do code de commerce, vol. 3, Paris 1821.

${ }^{14}$ L. Nouguier, Des tribunaux de commerce des commerçants et des actes de commerce: ouvrage contenant: 1. l'organisation ancienne et actuelle des tribunaux de commerce et les reformes qu'elle nécessite; 2. un traité complet des droits et devoirs des commerçants; 3. les regles diverses concernant les actes de commerce; 4. la compétence des tribunaux consulaires sur toutes les matières du droit; 5. la procédure suivie devant eux; 6. l'indication de toutes les arrêts et de l'opinion des auteurs; 7. un formulaire général des actes du ressort des tribunaux de commerce; 8 le texte de la législation, lois, décrets, ordonnances, royales, avis du conseil d'état, arrêtés ministériels; 9. la table des noms des auteurs et des ouvrages que l'on peut consulter sur ces différents sujets, vol. 2, Paris 1844; idem, Des lettres de change et des effets de commerce en général : ouvrage contenant: $1^{\circ} \mathrm{Un}$ traité; $2^{\circ}$ La jurisprudence; $3^{\circ}$ L'opinion des auteurs; $4^{\circ}$ La législation actuelle de la France; $5^{\circ} \mathrm{La}$ législation internationale, vol. 2, Paris 1839. 
gronów ${ }^{15}$, Brawardów ${ }^{16}$; w kraju pojęcia handlowe nieustalone, rzec można, źle pojmowane, słowem prawie znikąd naukowej pomocy. Byłże pierwszy tłómacz kodexu handlowego w pracy swej wsparty publiczną jaką radą, objaśniony światłą krytyką? - Nie; błędy nawet przez niego popełnione uzyskały niejako moc prawa. Szczególna obojętność i nietroszczenie się ludzi powołania ówczasowej epoki!" [was almost entirely left to his own powers and could not draw on the knowledge and explanations of the authors who made such huge strides in the advancement of this science in the course of his work. There were no Delvincourts, Pardessuses, Vincenses, Nougiers, Rogrons, and Bravards yet; trade terms were not as yet determined in the country, so one could say they were misunderstood; in short, he could not expect scientific help from any quarters. Was the first translator of the Commercial Code supported in his work by some public advice or was he given constructive enlightened criticism? - No; as it were, even the mistakes he made obtained legal validity. It shows distinctive indifference and a lack of care on the part of contemporary people of vocation!]. ${ }^{17}$

Skorochód-Majewski published another translation of Code de commerce, which was called "Edycja Druga Poprawna" [The Second Correct Edition], ${ }^{18}$ in 1811 as well as another one in $1834 .{ }^{19}$ It was Heylman's opinion that the changes which

15 J.A. Rogron, Code de commerce expliqué par ses motifs et par des exemples; avec la solution, sous chaque article, des difficultés, ainsi que des principales questions que présente le texte et la définition de tous les termes de droit. Ouvrage destiné aux étudiants en droit, aux négociants, aux personnes chargées d'appliquer la loi commerciale, et à toutes celles qui, désirant la connaître, n'ont pu en faire une étude spéciale, Paris 1825.

${ }^{16}$ P. Bravard-Veyrières, Manuel de droit commercial, un traité élémentaire sur chaque titre du Code de commerce, le texte des Ordonnances de 1673 et 1681, et le texte du Code, une analyse des tous les articles du Code réduits en questions et des formules d'actes, Paris 1838.

17 J.C. Sławianowski, Uwagi nad kodexem handlowym przez J.Ro. Warszawa w druk. S. Orgelbranda, 1845, IV $i 95$ str. [Comments on the Commercial Code by J.Ro., Warsaw in the printing house of S. Orgelbrand, 1845, IV and 95 pages], Biblioteka Warszawska [Warsaw Library], vol. 1, 1846, p. 364.

${ }_{18}$ Kodex handlowy, z zlecenia JW. Ministra Sprawiedliwości przełożony przez Walentego Skorochod Maiewskiego, P. A. X. W. T. K. W. P. N. przybranego członka, Edycya Druga Poprawna [Commercial Code as ordered by the Honourable Minister of Justice and translated by Walenty Skorochód Majewski, P. A. X. W. T. K. W. P. N. adopted member, The Second Correct Edition], Warsaw 1811.

${ }^{19}$ Kodex handlowy, wraz z Powodami z Zlecenia JW Ministra Sprawiedliwości przez Walentego Skorochod Maiewskiego główno-krajowego archiwisty i pisarza akt Król: Pol: b. depu: na seymy, orderu nieskazitelnéy stużby publi: emeryta, przełożony. Edycya trzecia poprawna [Commercial Code together with the Reasons as ordered by the Honourable Minister of Justice and translated by Walenty Skorochód Majewski, the head archivist of the country and the scribe of King's acts, former deputy to sejms, the order of untarnished public service, retired, superior. The Third Correct Edition], Warsaw 1834. In Porównanie pobieżne... [A cursory comparison...], p. 83, Heylman only mentioned the 1808 and 1834 versions. However, in Kodex handlowy. Przekład z przypiskami przez Augusta Heylmana, sędziego appellacyjnego [The Commercial Code. A translation with comments 
had been introduced there were minor ones in comparison with the first edition. ${ }^{20}$ However, the translator already removed the French remnants in the second edition of the translation. Moreover, in the $3^{\text {rd }}$ edition, he introduced a parallel method of numbering the articles of the Code, which was commonly adopted, alongside the one he originally employed.

Subsequently, Damazy Dierożyński supposedly translated a commentary by Joseph-André Rogron's on Code de commerce before 1831. However, as Heylman related, only the comment to article 55 was published and its manuscript was lost. ${ }^{21}$ The next complete translation of the Commercial Code was published years later, in 1845, in Cracow. This edition was published together with the Civil Code and the Code of Civil Procedure. This publication was created by Jan Kanty Hieronim Stefan Rzesiński. ${ }^{22}$ The aforementioned judge, Sławianowski, carried out the critique of these translations. ${ }^{23}$

The following translation, which was done by August Heylman, was published in 1847. It differed from the remaining Polish translations to a large extent. This was mainly connected with the fact that the author took advantage of two Ger-

by August Heylman, a Court of Appeal judge], Warsaw 1847, p. I, he already mentioned the 1808 translation and the two corrected editions without mentioning the date of their publication. Similarly, J. Namitkiewicz, in the introduction to his translation of Code de commerce, wrote about only two translations (1808 and 1834) by W. Skorochód-Majewski. However, he clearly emphasized that the 1834 edition was entitled "Edycya trzecia poprawna" [The Third Correct Edition].

${ }^{20}$ Kodex handlowy. Przektad z przypiskami... [Commercial Code. A translation with comments...], p. I.

${ }^{21}$ Ibidem. However, a translation by Dzierożyński of the commentary by Rogron to the Code of Civil Procedure of 1806 was preserved: idem, Kodex postępowania cywilnego, wyluszczony przez swoje powody -i przez przykłady; z rozwiazaniem pod każdym artykułem trudności, a oraz głównych zagadnień, nastręczajacych się $w$ texcie; jako też z opisaniem znaczenia wszelkich wyrazów prawnych. Dzieło, przeznaczone dla uczących się prawa i dla osób trudniacych się przystosowaniem przepisów procedury, i dla wszystkich innych, którzy życza poznać takowe, a nie mogli oddawać się szczególney ich nauce, podlug drugiéy edycyi przez J.A. Rogrona, Adwokata w Radzie Królewskiéy i przy Sadzie Kassacyinym z francuzkiego - przełożone na polski język z zastosowaniem do zmian zasztych $w$ prawodawstwie polskim, $i$ wtasnem staraniem $i$ naktadem wydane [The Code of Civil Procedure explained through its reasons - and through examples; with a comment to each article as well as to major issues present in the text; together with a description of meaning of every legal term. The work is intended for students of law and for people working to adjust the regulations of the procedure, and to all others who wish to learn them but could not study them in detail, according to the second edition by J.A. Rogron, an Attorney in the King's Council and in the Court of Cassation - translated from French to Polish w the application of changes which had taken place in Polish legislation, and published by own effort and expenditure], vol. 1 and 2, Warsaw 1829.

22 J.H.S. Rzesiński, Trzy kodexa francuzkie. Cywilny, postępowania sądowego i handlowy. $W$ przekładzie poprawnym, $z$ dołaczeniem zwiazkowych między soba artykułów [Three French Codices, Civil, Civil Procedure, and Commercial. In a correct translation with an addition of articles connecting them], Cracow 1845.

23 J.C. Sławianowski, Uwagi... [Comments on...], pp. 362-374. 
man translations ${ }^{24}$ as well as of the commentaries to Code de commerce made by Rogron, ${ }^{25}$ Pierre Bravard-Veyrières,${ }^{26}$ and Jean-Marie Pardessus ${ }^{27}$ in his work. Additionally, Heylman planned to formulate a commentary to the Code which would correspond to Polish conditions. Nevertheless, he gave this idea up and used as an excuse a lack of literature on commercial law as well as the all too numerous controversies connected with the application of particular provisions in judicial decisions of Polish courts. ${ }^{28} \mathrm{He}$ limited himself to a small number of footnotes which indicated the amendments to Code de commerce in France or ones which took the specificity of Polish territories into consideration. One would expect a significantly larger number of the second type of footnotes for a number of reasons. Especially if one takes into consideration the scientific passion of this author, who was so fond of criticizing others, and who was a doctor of both laws after his graduation from the universities in Berlin and Göttingen. But the first and foremost reason is the fact that Heylman not only had easy access to the preserved data, such as the information concerning the shape of the commercial judiciary on Polish territories, but also proper qualifications to analyze and interpret them thanks to the years he served as a judge in the Kingdom of Poland and thanks to the time he served as the vice-president of the Court of Appeal in Warsaw. ${ }^{29}$

One year later, in 1848, the translation by Jan Szymanowski, an assistant public prosecutor at the Court of Appeal of the Kingdom of Poland, was published

${ }^{24}$ From among the various German translation of the Commercial Code which had been published until the end of the 1st half of the 19th century, two versions were considered the best by Heylman and they constituted the basis of his work. The first translation was published, without any publication date, in Frankfurt am Main and in Leipzig under the following title: Die fünf französischen Gesetzbücher, nach den besten Uebersetzungen, nebst den bezüglichen Gezetzen, Dekreten, Staatsraths - Gutachten, Ministerial - umschreiben, und allen seit 1814 in den Landen des linken Rheinufers und später in dem Rheinkreise, ergangenen Gesetzen, Verordnungen und Instructionen, wodurch die französische Gezetzgebung aufgehoben, abgeändert und erläutert worden. The second one entitled Das Handelsgesetzbuch der Königlich Preussischen Rheinprovinzen übersetzt und erläutert von C.A. Broicher und F.F. Grimm Königlichen Landgerichtsräthen was published in Cologne in 1835. The latter translation included an additional collection of decisions of the French Court of Cassation. See more in: Kodex handlowy. Przektad z przypiskami... [The Commercial Code. A translation with comments...], p. II et seq.

25 J.A. Rogron, Code de commerce...

${ }^{26}$ P. Bravard-Veyrières, Manuel de droit commercial...

27 J.-M. Pardessus, Cours de droit...

${ }^{28}$ Kodex handlowy. Przektad z przypiskami... [The Commercial Code. A translation with comments...], p. III.

${ }^{29}$ He did not take advantage of this opportunity neither in the first nor in the second work on the organization of the judiciary. Compare: O saqdownictwie w Królestwie Polskiém. Wykład historyczny [Judiciary in the Kingdom of Poland. A history lecture], Warsaw 1834. A. Heylman, Historya organizacyi sadownictwa w Królestwie Polskiem [The history of the organization of the judiciary in the Kingdom of Poland], Warsaw 1861. Furthermore, these works contain untrue claims. 
together with a translation of the commentary by Rogron into Polish. ${ }^{30}$ Without wishing to disparage Szymanowski's contributions to the dissemination of knowledge pertaining to French jurisprudence in the field of commercial law, one ought to notice that the title of his work is slightly misleading. As a matter of fact, he translated Rogron's work into Polish and added excerpts from other authors' commentaries in the footnotes. However, these excerpts, the use of which is proudly emphasized in the preface to Szymanowski's publication, ${ }^{31}$ replicate in fact the footnotes as well as the choice of citations which were included in the creatively supplemented and expanded re-edition of Claude-Ėtienne Delvincourt work by Emmanuel Victor Godet which was published in Brussels. All of Szymanowski's additions simply constitute a translation of the Belgian version (all of which he failed to point out). ${ }^{32}$ Moreover, there are relatively few remarks pertaining to the specificity of the Polish lands. ${ }^{33}$

The eighth translation, if one takes into consideration Dzierożyński's lost manuscript, of Code de commerce together with other French codes was published between 1860 and 1863 . The text was enriched by the contents of legal acts which had been promulgated after the Code had been introduced into Polish lands and thus the Code's articles were complemented or amended. ${ }^{34}$ Particular articles were also provided with referrals to the Code's and to other acts which were connected with it. Stanisław Zawadzki was the author of this edition but four more lawyers were supposedly involved in the creation of this publication to a large extent. ${ }^{35}$ Unfortunately, neither Zawadzki nor Heylman who made this suggestion supplied the names of these potential co-authors.

${ }^{30}$ Wykład prawa handlowego przez J.A. Rogrona, adwokata przy Radzie Stanu i przy Sadzie Kassacyjnym Francuzkim, przełożyt Jan Szymanowski, podprokurator przy Sadzie Appellacyjnym Królestwa Polskiego z dodaniem przypisów z najcelniejszych autorów czerpanych, jakoteż własnych uwag zastosowanych do prawodawstwa i jurysprudencyi krajowych [Commercial law by J.A. Rogron, an Attorney in the Council of State and in the French Court of Cassation, translated by Jan Szymanowski, an assistant prosecutor in the Court of Appeal of the Kingdom of Poland, with an addition of footnotes from the most apposite authors and drawn also from author's own comments pertaining to domestic legislation and jurisprudence], Warsaw 1848.

${ }^{31}$ Ibidem, pp. IV-V.

${ }^{32}$ V. Godet, Institutes de droit commercial ou examen des principales questions qui peuvent s'élever sur les matières commerciales; par Delvincourt, ancien professeur et doyen de la Faculté de droit de Paris, membre du Conseil royal de l'instruction publique, édition augmentée en Belgique de la conférence de l'ouvrage avec la doctrine, conforme ou contraire, de MM. Pardessus, Vincens, Frémery, et de la législation et de la jurisprudence belges, Brussels 1838.

${ }^{33}$ With reference to commercial judiciary, compare with: Wyktad prawa handlowego przez J.A. Rogrona... [Commercial law by J.A. Rogron...], pp. 715-779.

${ }^{34}$ Prawo cywilne obowiazujące w Królestwie Polskiém wydat Stanisław Zawadzki, refferent Kom. Rza. Sprawiedliwości [Civil law in force in the Kingdom of Poland published by Stanisław Zawadzki, a clerk of the Ruling Committee of Justice], vol. 3, Warsaw 1860-1863.

${ }^{35}$ A. Heylman, Porównanie pobieżne... [A cursory comparison...], p. 83. 
The next translation was published in 1916 and, according to Jan Namitkiewicz, it was modeled on the Zawadzki translation. However, this edition employed a more modern language. ${ }^{36} \mathrm{He}$ did not point to the titles of the works or even to the authors' names though. The only certain thing is that they were two lawyers and their initials were J.F. and St. G. Similarly, Władysław Józef Szatensztejn clearly stated in the preface to the edition of The Commercial Code which he authored that he had based his work on the translation by "J.F. i St. G., które należy uznać za najbardziej ścisłe" [J.F. and St. G. which needs to be acknowledged as the most precise one.${ }^{37}$ Both authors probably referred to a work entitled Kodeks handlowy: nowy przektad przez J.F. i St. G. [The Commercial Code: a new translation by J.F. and St. G.] (Warsaw 1916). The authors of this work were Jan Fidler and Stanisław Goldsztein. This translation was also added to a more comprehensive volume on private law which was published by Fidler, namely Prawo cywilne obwiazujace w Królestwie Polskiem. Wydanie obejmuje: Kodeks cywilny Królestwa Polskiego. Prawo o matżeństwie 1836. Kodeks cywilny Napoleona (Księga II i III). Ustawy Hipoteczne oraz Kodeks Handlowy [Civil Law in force in the Kingdom of Poland. The edition includes: the Civil Code of the Kingdom of Poland. The Marriage Law of 1836. The Napoleonic Civil Code (Book 2 and 3). The Mortgage Law as well as the Commercial Code] (Warsaw 1916). The translation was supplemented by a list of articles included in Code de commerce which had undergone a change due to the carried out judicial reform in the Kingdom of Poland in the seventies of the $19^{\text {th }}$ century. Moreover, it was complemented by the regulations pertaining to commercial law issued by the occupation authorities between 1915 and 1916. Book 2 pertaining to maritime commerce was omitted. The rationale behind this omission was that it did not apply to the Kingdom of Poland due to its geographical location.

Finally, a translation edited by Jan Namitkiewicz was published in 1918. The scope of the contents of this edition exceeded the material which had been collected for the previous editions. This was due to the fact that the authors did not only collect referrals to particular articles of the Commercial Code itself and other acts which were connected with a particular provision in accordance with the formula set by Zawadzki. They also collected regulations from the sphere of commercial law which had been promulgated by the occupation authorities, judicial decisions of the $9^{\text {th }}$ Department of the Governing Senate as well as, above all, select theses

${ }^{36}$ L. Babiński, J. Namitkiewicz, B. Ślaski, Kodeks handlowy obowiazujący w Królestwie Polskiem, nowy przektad polski wraz z jurysprudencya [The Commercial Code in force in the Kingdom of Poland, a new Polish translation with jurisprudence], Warsaw 1918, preface.

37 W.J. Szatensztejn, Kodeks handlowy obowiazujący w b. Królestwie Kongresowem, ustawy i rozporzadzenia uzupetniajace i związowe wraz z orzecznictwem [The Commercial Code in force in the former Congress Poland, laws as well as supplementary and related regulations together with judicial decisions], Warsaw 1932, p. IV. 
from French case law by the French Court of Cassation. The authors themselves emphasized that they modeled their work on a multi-author publication published by The Warsaw Law Society - Prawo cywilne obowiazujace w Królestwie Polskiem [Civil law in force in the Kingdom of Poland] of $1914 .{ }^{38}$ However, a serious shortcoming of this edition was that a translation of Book 2 was not done once again. The rationale provided by the authors was the same one as the arguments which had been provided by Fidler and Goldsztein. ${ }^{39}$ The translation of the contents of the Code itself was carried out under the direction of Bolesław Ślaski, an eminent expert in legal terminology, by a team of lawyers, namely Leon Babiński, Adam Dziedzicki, Wacław Kinel, Kaziemierz Paszkowicz, Stanisław Skonieczny, Stefan Urbanowicz and Karol Wellisch. They also dealt with the choice of theses from French case law. On the other hand, the theses from the judicial decisions of the $9^{\text {th }}$ Department were compiled by Namitkiewicz, who also oversaw the general editorship of the publication. The translation was so successful that the first edition was sold out in less than three months and, in effect, a second edition was published with minor changes. ${ }^{40}$ Several years later, another work by Namitkiewicz was published-Kodeks handlowy obowiazujący w b. Królestwie Polskiem: kodeks handlowy, prawo wekslowe i czekowe wraz z ustawami dopetniajacymi oraz orzecznictwem polskiem, francuskiem, rosyjskiem i niemieckiem [The Commercial Code in force in the former Kingdom of Poland: the Commercial Code, Promissory note law and Cheque law together with supplementary laws as well as Polish, French, Russian, and German case law] (Warsaw 1927).

Władysław Józef Szatensztejn published the aforementioned last translation of Code de commerce in 1932. It was expanded with regulations as well as supplementary and related laws. He also developed case law of Polish and French courts. He drew his knowledge pertaining to the subject from "Orzecznictwo Sądów Polskich" [Judicial decisions of Polish courts], "Przegląd Prawa Handlowego" [A Review of the Commercial Law], the translation by Namitkiewicz, "Wiadomości Urzędu Patentowego" [Patent Office News], a collection of court sentences from the area of bankruptcy law authored by Adam Słomiński, a collection of case law by JeanBaptiste Sirey as well as a coursebook by Léon Lacour and Jacques Bouteron. ${ }^{41}$ The main point of interest did not lay in the contents of Code de commerce itself,

${ }^{38}$ L. Babiński, J. Namitkiewicz, B. Ślaski, Kodeks handlowy... [Commercial Code...], preface.

${ }^{39}$ L. Babiński, J. Namitkiewicz, B. Ślaski, Kodeks handlowy obowiązujacy w Królestwie Polskiem, nowy przektad polski wraz z jurysprudencya, wydanie drugie, przejrzane i poprawione [The Commercial Code in force in the Kingdom of Poland, a new Polish translation with jurisprudence, second edition, reviewed and corrected], Warsaw 1919, p. 106.

${ }^{40}$ Ibidem, preface to the 2 nd edition. The second edition was also printed in 1920 (with a tiny spelling mistake in the title: "wydanie drugie, przejrzane i poprawione" [Translator's note: the spelling of the last word is in the feminine form and it should be a neuter word in Polish]).

${ }^{41}$ L. Lacour, J. Bouteron, Précis de droit commercial, Paris 1928. 
which was published only in fragments ${ }^{42}$. The crux of the matter was in the detailed contents of numerous laws and regulations from the area of generally understood commercial law together with regulations from different fields pertaining to issues raised in a particular provision of the $\mathrm{Code}^{43}$ or in its provisions in force in other lands. As a result, the title of Szatensztejn's work does not entirely reflect its contents. ${ }^{44}$

It is difficult to unambiguously evaluate all of these translations. The task is even more challenging due to the fact that they were published over the course of 100 years. One ought to presume that as time passed and it became possible to take advantage of the body of work of the predecessors, the subsequent translations of the Code should have been better and better. However, it is unfortunate that even a cursory comparison of particular editions does not allow one to unequivocally formulate such a thesis. While translating a legal text, "myśl i duch prawa, według rachuby, iż tak rzekę, matematycznéj, na pieczy miéć potrzeba, ażeby tłómaczenie na mylną interpretacją prawa nie nawiodło: jednakże osiągnięcie tego celu zależy po wielkiéj części, od zachowywania, z równą troskliwością, właściwego ducha i przyrodzonego toku języka, na który się tłómaczy" [the thought and spirit of law, according to a mathematical account (so to speak), one needs to take care not to lead a translation to an erroneous interpretation of the law: however, achieving this goal depends to a great extent on maintaining the proper spirit and the natural flow of the language into which one translates with equal care]. ${ }^{45}$ And exactly with this "spirit and natural flow" of Polish, the majority of authors had particular problems. It seems then that even though a minute analysis of the whole content of each translation of the entire Code is not purposeful, it is nevertheless worthwhile to present several examples.

First and foremost, Code de commerce started to use the term commerçant and thus it departed from the term marchand (Polish "kupiec") which had been used in Ordonnance du commerce of 1673 . The term commerçant included in its scope not only négocians, marchands et banquiers but also all others who carried on commerce and made it their habitual profession (article 1). Consequently, the term

${ }^{42}$ Due to the loss of force, the following articles were omitted in the printed version: $17,21,23$ (the last passage), 25, 29-37, 40, 42-46, 51-70, 71-90, 110-189, 190-436, 497, 615-630, 636-637, $639,642-648$.

${ }^{43}$ For instance, the 1st article of the Commercial Code which delineates who should be considered a trader was provided with, among others, appropriate regulations of the Act of 18 July 1924 of basic duties and rights of privates in the Polish Army (Journal of Laws no. 72, item 698) or the regulation of 15 May 1928 (Journal of Laws no. 71, item 643) published in order to execute it, which barred privates from "wykonywania zawodów cywilnych i oddawania się zajęciom ubocznym" [practicing civilian professions or pursuing side activities].

${ }^{44}$ W.J. Szatensztejn, Kodeks handlowy... [The Commercial Code...].

${ }^{45}$ A. Heylman, Porównanie pobieżne... [A cursory comparison...], pp. 83-84. 
commerçant had a significantly wider scope of meaning than the word merchant-it corresponded to the present-day meaning of the term "entrepreneur." However, the etymology of the term commerçant was initially blurred in Poland. Ever since Code de commerce was introduced in the Duchy of Warsaw, people who employed the French Commercial Code were misled by the first version of the translation of the Code by Skorochód-Majewski. He consistently translated the term commerçant by using the word "kupiec" and, as a result, he caused interpreters to distort the meaning of the term. Skorochód-Majewski corrected the flagship article 1 by using the term "handlujący" (traders) in the 1811 edition, although he continued to employ the term "kupcy" (merchants) in articles 6 and $8{ }^{46}$ The same issue occurred in the third edition. The following translations, as a rule, corrected this issue. However, the term "małoletni kupcy" (underage merchants) still appears in article 6 and "żony kupcowe" (merchants' wives) is present in article 7 of the Rzesiński version, while the former can be also found in the translation by Zawadzki.

Already the $1^{\text {st }}$ article of Code de commerce posed various problems for translators. According to the original wording of the regulation: "Sont commerçants ceux, qui exercent des actes de commerce, et en fout leur profession habituelle". Skorochód-Majewski translated this in his 1811 edition into: "Handluiącymi są ci, którzy się działaniami Handlowemi trudnią i to zatrudnienie, za szczególny do życia sposob obieraią" [Traders are people who deal with trading activity and they choose this occupation as a way of life $]^{47}$ and Heylman considered the phrase "działaniami handlowemi trudnią" [deal with trading activity] as one which especially "nieodpowiadające używalności języka polskiego" [did not correspond to the use of the Polish language]. ${ }^{48}$ The use of this expression is surprising to a certain extent as it is completely certain that a proper equivalent of actes de commerce

${ }^{46}$ Art. 1. Handluiącymi są ci, którzy się działaniami Handlowemi trudnią i to zatrudnienie, za szczególny do życia sposob obieraią. Art. 6. Kupcy małoletni, do prowadzenia Handlu w sposób powyższy upowaźnieni, mogą się co do swojego nieruchomego maiątku zobowiązywać i tenże Hipotecznie długami obciążać. [...]. Art. 8. Każdy kupiec powinien utrzymywać Xiążkę, Dziennik, któryby przedstawiał dzień po dzień, długi, tak mu należne iako też od niego winne, (Activa i Passiva) działania iego Handlu, iego zapisywania i odbierania towarów (Negocyacye) przyimowanie lub przenoszenie (akceptowanie indossowanie) wszelkiego rodzaju wexlów i kursuiących papierów; a w ogólności wszystko to, co pod iakiem bądź nazwiskiem: odbiera lub wypłaca, i ktoryby wyszczególniał ilość pieniędzy, co miesiąc na utrzymanie domu wyłożonych: wszystko to bezwględnie na inne w Handlu używane Xiążki, lecz ktorych utrzymywanie tak nieodbicie potrzebnem nie iest. [...]). W. Skorochód-Majewski, Kodex handlowy, z zlecenia JW. Ministra Sprawiedliwości przełożony przez Walentego Skorochód Majewskiego, P. A. X. W. T. K. W. P. N. przybranego członka, Edycya Druga Poprawna [The Commercial Code as ordered by the Honourable Minister of Justice and translated by Walenty Skorochód Majewski, P. A. X. W. T. K. W. P. N. adopted member, Correct Second Edition], Warsaw 1811, p. 1.

${ }^{47}$ Likewise in the 1834 edition.

${ }^{48}$ A. Heylman, Porównanie pobieżne... [A cursory comparison...], p. 85. 
was employed in Polish in the form of "czynności handlowe" [commercial acts] in the beginning of the $19^{\text {th }}$ century. This is confirmed by by the use of the expression used by the same author in his first edition in 1808 in which he wrote: "Kupcami są ci, którzy się czynnościami handlowemi trudnią [...]" [Merchants are the people who deal in commercial acts (...)]. Szymanowski's translation of actes de commerce was "czyny handlowe" [commercial deeds]. This term was adroitly commented on by Heylman who said that "do czynów handlowych, handlujący zwykle nie podnoszą się, zajmując się jedynie interesami korzyść pieniężną przynoszącemi. Mówimy: «czyny bohaterskie» po Niemiecku «Heldenthaten», nigdy zaś czyny handlarskie lub handlowe, "Handelsthaten»" [in reference to commercial deeds, traders do not engage themselves in them and instead they only deal in business which is financially profitable. We say «heroic deeds», in German "Heldenthaten», however, we never say commercial or commerce deeds, "Handelsthaten»]. ${ }^{49}$ A similar mistake was made in the Zawadzki edition who additionally interchangeably employed the terms "czyny handlowe" [commercial deeds] (article 632) and "czynności handlowe" [commercial acts] (article 1) and he did it inconsistently. A much more accurate translation was included in the publication by Heylman: "Kto czynności handlowe wykonywa i na tém swój sposób zarobkowania zakłada, jest handlującym" [Who conducts commercial acts and earns profit this way is a trader]. However, he deviated in his translation from the plural form used in the original text which Rzesiński, Fidler and Goldsztein as well as Namitkiewicz all managed to avoid. The last author wrote: "Handlującymi są ci, którzy czynności handlowe wykonywają i jako zwykłe swe zatrudnienie je traktują" [Traders are those who conduct commercial acts and treat them as their habitual profession]. This regulation was slightly modernized by Szatensztejn who translated article 1 thus: "Handlującymi są ci, którzy wykonywają czynności handlowe, uprawiając je zawodowo" [Traders are those who conduct commercial acts as professional work].

Another example is the translation of the French expression se règle which was used in article 18 in relation to partnership agreements. According to the edition by Rzesiński and Szymanowski: "Kontrakt współki urządza prawo cywilne, szczególne ustawy handlowe i umowy stron" [A partnership contract settles civil law, particular commercial acts and agreements between the parties] where the word "urządza" [settle] constitutes in Polish an overly literal translation of the verb règler. Zawadzki's translation was not much better as it employed "urządza się" [is settled by]. The term used by Skorochód-Majewski in the first edition seems even more inaccurate: "Kontrakt towarzystwa uważa się stosownie do prawa cywilnego [...]" [A contract of a partnership is regarded according to civil law (...)]. Also incorrect

\footnotetext{
${ }^{49}$ Ibidem.
} 
but a much more understandable term was used by the same author in the 1811 and 1834 editions: "Prawidła kontraktu współki, czerpaią się z Prawa Cywilnego [...]" [Rules of a contract of a partnership are drawn from Civil Law (...)]. Heylman's translation is a much better reflection of the essence of the French regulation according to which "Kontrakt współki podlega przepisom prawa cywilnego [...]" [A contract of a partnership is subject to the provisions of civil law (...)] which was repeated in the translation by Namitkiewicz and Szatensztejn. They just used a more modern version of the word "partnership" which was spótka in Polish instead of the older wspólka. Fidler and Goldsztein adopted the following version: "Kontrakt spółki sporządza się podług prawa cywilnego [...]" [A contract of a partnership is drawn up according to civil law (...)].

Much bigger discrepancies occurred in certain situations. The translations frequently not only did not fully express the whole meaning of a particular regulation but they were even in certain instances in complete contradiction to the original text. An example of this was Zawadzki's translation of the original En cas de partage, les arbitres nomment un sur-arbitre [...] from article 60 into "w razie równości zdań sędziowie polubowni obierają superarbitra" [in case of equality of opinion, arbitrators of a tribunal choose a superarbitrator] which means "zgodność zdań" [conformity of opinions]. The same mistake was repeated by Fidler and Goldsztein. Skorochód-Majewski, Rzesiński, Heylman, and Szymanowski translated en cas de partage into "w razie/w przypadku/w zachodzącéj różności zdań" [in case of/in the event of/if a difference of opinion occurs] which only partially expressed the meaning of this phrase, but at least it did not contradict the original meaning. It is worth noting here that the Polish translators were not the only ones who failed to avoid certain mistakes. As Heylman mentioned, the translations into German, on which he had based his work, had also contradicted the French version in the use of the phrase Im Falle der Stimmengleichheit..$^{50}$ However, a mistake such as this one is inexcusable because partage indisputably means "podział" [a division], "podzielenie" [a split], "rozdzielenie" [a separation].$^{51}$ The point is not only that there are differences of opinion but that there is also an equal number of contrary opinions. The complete meaning of this expression was finally provided in the translation by Namitkiewicz. He translated en cas de partage into "w razie równego podziału zdań" [in case of an equal division of opinions].

As a result, despite the efforts of various authors to translate Code de commerce into Polish, it is difficult to choose which version is the most faithful to the original. There were jarring mistakes in some editions, which stemmed from a lack of

${ }^{50}$ Ibidem, p. 90.

${ }^{51}$ P. Dahlmann, Nouveau dictionnaire de poche français-polonais, $14^{\text {th }}$ edition, vol. II, Berlin [n.d.], p. 830 . 
knowledge of the French commercial law. On the other hand, other editions omitted parts of the Code using as an excuse the fact that particular norms were not in force, did not pertain to, or lost force in Polish territories. However, a researcher's integrity requires them to refer to the original for this very reason. 